\title{
Measuring business process performance in the seed industry
}

\author{
Мерење перформанси пословних процеса у семенској \\ индустрији
}

Goran Petrović*

Institute of Field and Vegetable Crops, Novi Sad, Serbia, goran.petrovic@ifvcns.ns.ac.rs

\begin{abstract}
The literature that generally deals with business processes is extensive, but, at the same time, there is a noticeable lack of it in some specific areas, such as the seed industry. The paper presents the relations between the main participants in the process of creating new values and gives examples of business success indicators in the organization operating in the seed industry. The presented results are based on the author's research through questionnaires and interviews with employees in this field, while the aim of the research was to review business processes in the seed industry, identify the key ones, and determine the models for their performance management.
\end{abstract}

Keywords: seed industry, business processes, performance

JEL classification: M21, L25, Q10

Сажетак: Литература која се генерално бави пословним процесима је обимна али је истовремено приметан недостатак исте у неким специфичним областима, попут семенске индустрије. Рад приказује релације између главних учесника у процесу стварања нових вредности и наводи примере показатеља успешности пословних процеса организације у семенској индустрији. Приказани резултати настали су на основу ауторског истраживања кроз упитнике и интервјуе са запосленима у овој области, а циљ истраживања је сагледавање пословних процеса у семенској индустрији, идентификација оних кључних и утврђивање модела за управљање њиховим перформансама.

Кључне речи: семенска индустрија, пословни процеси, перформансе

JEЛ класификација: M21, L25, Q10

\section{Introduction}

Numerous literature dealing with business process management clearly indicates that organizations can improve their performance by adopting the "process view" of business (Davenport, 1993; Burlton, 2001; McCormack \& Johnson, 2001). Improvement in corporate performance actually depends directly on the efficiency of business processes and that is why building a system that will enable this type of management is one of the leading tasks of managers (Harmon, 2003). From that point of view, an organization's performance stems from the performance of its business processes.

Management of business processes and their performance can be examined through different approaches:

* Corresponding author 
The quality control approach has brought numerous methods, tools and techniques (TQM, Six Sigma, Lean, TOC ...) which are sometimes combined depending on the needs of the organization, while the ultimate goal is to raise product quality and establish a more efficient business at lower costs, with improved services and satisfied customers (Joglekar, 2003; Salah, et al., 2009; Goldratt \& Cox, 1986; Basu, 2008). The managerial approach is aimed at harmonizing the processes with the organization goals through continual process definition, monitoring and improvement. Most researchers adopted the holistic approach to process performance management with particular importance on viewing the process from different perspectives (Kaplan \& Norton, 1993; Neely, et al., 2002; Maskell, 1992). Rummler \& Brache (1995) made a great contribution to management, claiming that a classic hierarchical approach to an organization is insufficient, as it is an adaptive system where all processes (internal and external) are connected, and that successful management must not lose sight of other factors, such as users/customers or trends that affect a product or service. Rummler \& Brache's research resulted in an organizational matrix that illustrates business process management at three levels: organizational level, process level and the level of individuals/teams. The IT approach defines the role of information technology in a business process management system, while researchers reveal that technology alone does not correct bad processes, but accelerates them (Hammer, 1990). Other authors support this view and recognize technology as a tool in digital monitoring of business process performance, pointing out the necessity of a comprehensive approach and the holistic view of the entire system (Hammer \& Champy, 1993; Davenport, 1993).

There is no management without measurement, so it is impossible to manage business processes without measuring their performance (Kaplan \& Norton, 1993; Bititci, et al., 1997). Performance measurement for business process management purposes primarily refers to the identification of indicators of the current business process success. Building a system of business process performance indicators is a major challenge, so the more specific the activity of an organization is, the greater are the challenges associated with building and establishing a computer-aided system for measurement and (or) management of business process performance (Balaban, et al., 2010). One such emphatically specific area is the seed industry.

\section{Characteristics of the seed industry}

Laws in agriculture are specific and apply only to this industry. For example, The Law on Declining Soil Fertility (Komljenović, 2003), where additional investment of labor and exploitation of resources are not accompanied by an adequate, but a smaller amount of products. Problems in the production and marketing of agricultural products stem from the fact that agricultural production has a seasonal character and largely depends on "force majeure" (above all, but not exclusively on weather conditions). The same laws apply to the seed industry because, as part of the agricultural industry, it is engaged in the production of seeds for human and animal consumption.

The seed industry can be observed through three segments:

- Research and development, which deals with the development of new varieties 
(breeding process) and the development of technical and technological solutions

- Production, which includes activities related to seed production - propagation, production and processing of seeds, leading to a packaged product

- Business - activities related to handling processed seeds, marketing and commercialization/sales.

Breeding process is a time and financially demanding set of research activities with uncertain results. Research and the process of creating a new hybrid or variety can take up to 10 years, and it is possible that the final product does not give the expected results or the market does not accept it, so the research is treated as unsuccessful.

Seed production is regulated by the Law on Seed (ZoS, 2005), Rulebook on the recognition of varieties of agricultural plants $(\mathrm{Rb} 1,2006)$ and the Rulebook on the control of seed production $(\mathrm{Rb} 2,2010)$. Production control is performed by professional services authorized by the Ministry of Agriculture. The Rulebook determines seed quality thresholds for seed placement, including minimum purity, minimum germination, maximum seed moisture and the presence of weeds, which are precisely regulated by the Law for each plant species.

The process of seed placement between the producer and the final consumer includes several other related processes and participants (processors, warehouses, transporters, agricultural professional services, laboratories and providers of various services).

Seed industry is generally well regulated because the method of obtaining seeds and the production process are regulated by law. At the same time, despite good legislation, the industry is characterized by a high degree of uncertainty due to weather dependence, relations between market participants and internal procedural disorder of organizations (weaknesses).

\section{Research project and methodology}

Two empirical studies were conducted in 2019 with the aim of examining the knowledge of seed industry employees about business processes and general performance measurement. In addition, data were collected in order to establish classified critical success factors and performance indicators of business processes in the seed industry.

The first empirical research was based on the research question Q1: What business processes does a generic process model of an enterprise in the seed industry encompass? The research was realized by the method of interviews with a selected group of branch experts $(n=20)$, with the aim of gaining insight into their knowledge and attitudes regarding business processes and their performance management. Specific communication was established between the interviewer and the respondents wherein a semi-structured interview model was chosen (Gubrium \& Holstein, 2001). This model of data collection is characterized by a defined framework of planned questions which allow examiners the freedom to ask them. According to the number of participants, it is a "panel interview" where several interviewers (two interviewers participated in addition to the author) 
simultaneously interview respondents through a form of conversation, and everyone hears the answers (Čerović, 2013). Thus, more interviewers gain insight into the respondents' current knowledge and perception of the key elements of the business process performance management concept. The aim was to obtain necessary information and establish the basis of the questionnaire about practical achievements in the application of performance management concept in seed industry organizations.

The second empirical research included the questionnaire based on the analysis of the first. It is considered that researchers have two types of performance measurements at their disposal, objective and subjective ones, which should equally be used depending on the needs and goals of the research (Sandeep \& Harpreet, 2016). There is a correlation between objective parameters and their subjective assessment, and most of the empirical research carried out today use a questionnaire as a measurement instrument based on employees' subjective assessment. Regardless of subjectivity of the respondents about the shared information, this method of data collection is not subjective because the questionnaire offers an "objective way of collecting information about human knowledge, beliefs, attitudes and behavior of people" (Oppenheim, 1992). The questionnaire contains terminologically adjusted questions about the business process management practice and their performance applied by the respondents in their organizations, and the evaluation of the questionnaire was done in cooperation with selected domain experts. The aim of the second empirical research, which was conducted on a sample of $n=255$ respondents from different companies, was to gain insight into the extent to which employees in the seed industry are familiar with the purpose and content of the management performance concept, their attitude to the needs and opportunities of the concept application in business practice of organizations in the seed industry, as well as their view of critical factors and indicators of business success in the domain area. The analysis of the obtained results provided a well founded answer to the research question Q2: What are the indicators of the business processes efficiency of the organization in the seed industry?

\section{Selected research results}

The first research included a diagnostic interview conducted with the respondents, which showed that the respondents within the seed industry recognize several processes that synergistically form the "main stream" in which additional value is generated. Respondents listed five main processes in the seed industry: Research and Development, Production, Seed Processing, Storage (Warehousing and Inventory Management), Sales and Distribution.

Asked about the groups of participants in these processes, the respondents cited a wide range of occupations that they felt were involved. What came into prominence was the terminological inconsistency in defining the main concepts of determining the participants in the process. The analysis of the questionnaire and processing of the results, by grouping the answers, revealed two logical units of the main flow with the following participants: 
The first group refers to the development of the product and the production: researchers/scientists (breeders), technical associates (seed production) and technical assistants and laboratory assistants (auxiliary workforce). The second group includes sales and promotion: sales (wholesale and retail), promoters (field sales), and marketing.

The scheme of processes and participants in the seed industry shown in the figure below is presented through a conceptual model and is based on the research that included five main processes.

Figure1: Conceptual model of the seed industry

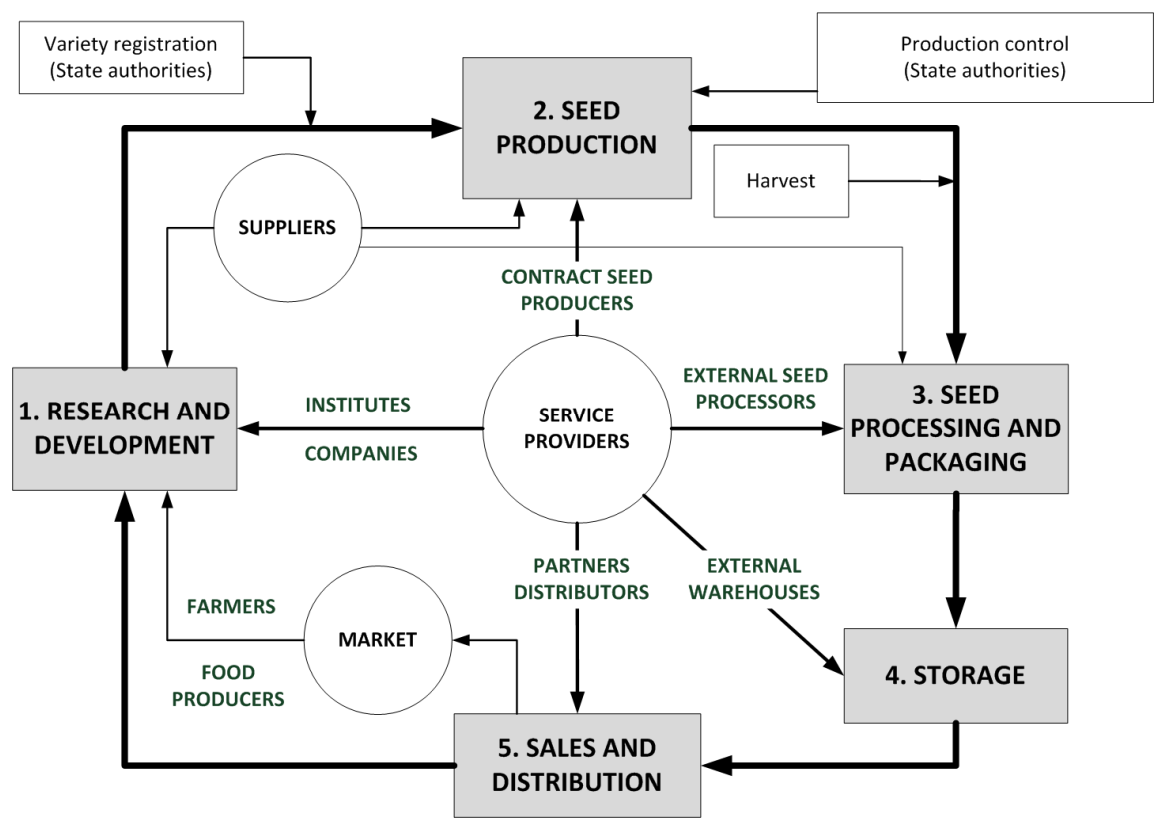

Source: the author

Research and development is done by organizations that are financially capable of supporting long-term (multi-year and even decades-long) research, while placing particular importance on ensuring continuity. They consist of companies which have their own research and development departments, scientific research institutes, and scientific and educational institutions (faculties).

Seed production based on a conceptual model implies multiplication of basic seed or commercial production, depending on the goals and needs of an organization, which can be two independent processes if the organization has such a capacity - independent production on a smaller scale and within research activities and larger (commercial) production in cooperation with partners as a common practice.

Seed processing, as the following stage, takes place in order to extract, prepare and 
package seeds of the highest quality, which must meet the prescribed standards and market requirements. The seed that fails to meet the legally prescribed quality standards cannot be certified, and is regarded and sold as grain.

Storage is a distinctive process which, depending on the plant species (and category of seeds), has specific rules and precisely defined procedures. According to the law, the processor must submit to the competent Ministry the data on storage space for separate storage of natural (unprocessed) and processed seeds of certain plant species, varieties and seed categories, as well as data on storage space for waste generated by seed processing (ZoS, 2005).

Sales and distribution are the last process chain link to the customer. This step includes several sub-processes and marketing activities, direct sales, sales through partners / distributors or exports. One partner can simultaneously participate in several different processes with different roles.

The entire process chain can be realized independently if the organization has such capacities, but in practice, most processes involve external services of partners.

The process model in Figure 2 shows business processes that generally take place in the seed industry. The model explains the creation of a value chain and lists the processes that affect it.

Figure 2: Framework model of specific business processes in the field of seed industry

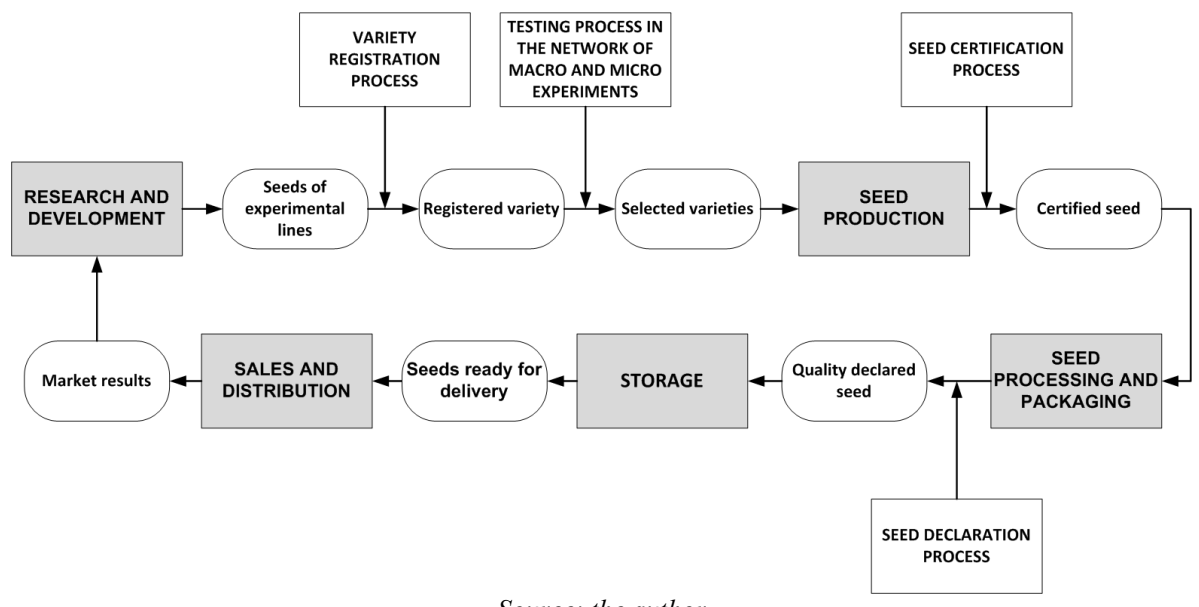

Source: the author

To define business process performance indicators (and the entire performance management system) of the organization properly, it is necessary to understand the hierarchy of strategic compliance. Some authors (Turajlić, et al., 2009; Watts \& McNairConnolly, 2012) present it in the form of a pyramid with the intention of simplifying the connection between the vision of the organization and its performance indicators. Basically, the connection spreads through the chain "Vision - Objectives - Strategy - CSF - KPI". 
The second empirical research was aimed at studying two important aspects of determining the success of an organization and its processes. The results of the research indicated, among other things, two elements of determining success of the organization and its processes: first, the critical success factors with performance indicators and second, process result indicators, with both groups emphasizing the key ones.

The organogram of these relations is presented in the figure below.

Figure3 - Hierarchy of strategic harmonization in the seed industry

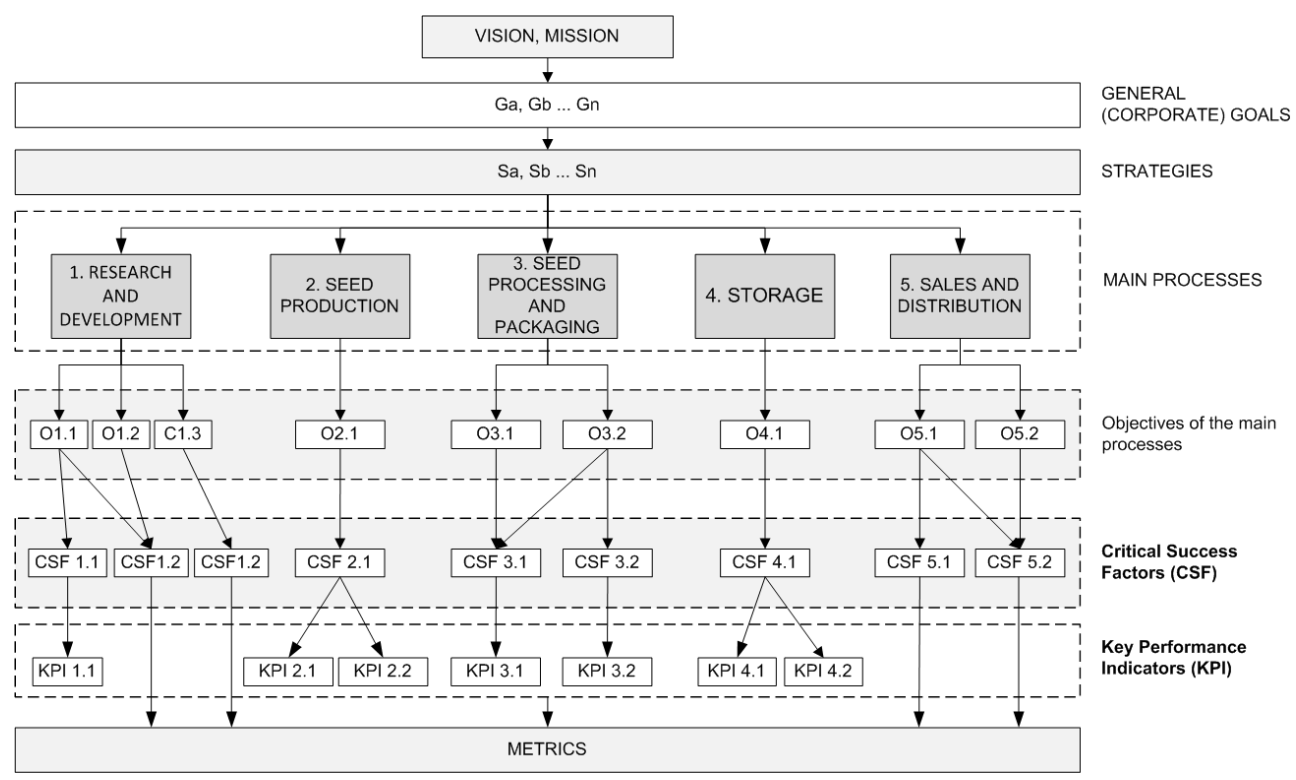

Source: the author

Performance indicators should be aligned with Critical Success Factors (CSF), which arise from the goals of the process, and they must be aligned logically with the organization's strategies and general goals, defined by the mission and the vision of the organization. CSFs indicate critical areas for achieving the desired results, i.e. the company's potential in relation to the desired results, as opposed to performance indicators which show the achieved performance and generally correspond to the values derived from business planning. According to Parmenter (2007), performance-related parameters include results indicators and performance indicators, emphasizing the existence of key indicators in both groups (KRI - Key Results Indicators, KPI - Key Performance Indicators).

Business process result indicators identified by respondents can be classified into groups as shown in the table below. 
Table 1: Groups of result indicators of the main business processes in the seed industry

\begin{tabular}{|l|l|}
\hline \multicolumn{1}{|c|}{ Business process } & Identified groups of result indicators \\
\hline Research \& development & $\begin{array}{l}\text { Development of varieties and hybrids } \\
\text { Scientific production }\end{array}$ \\
\hline \multirow{3}{*}{ Production } & $\begin{array}{l}\text { Production of varieties and hybrids } \\
\text { Individual effects of workers } \\
\text { Operational indicators }\end{array}$ \\
\hline Seed processing and packaging & $\begin{array}{l}\text { Operational indicators } \\
\text { Individual effects of workers }\end{array}$ \\
\hline \multirow{2}{*}{ Storage } & $\begin{array}{l}\text { Quantities and capacities } \\
\text { Quality } \\
\text { Costs } \\
\text { Operational indicators of warehousing }\end{array}$ \\
\hline Sales and distribution & $\begin{array}{l}\text { Placement indicators } \\
\text { Financial indicators }\end{array}$ \\
\hline
\end{tabular}

Source: the author

A wide range of data collected in the survey contains detailed tables with indicators for all identified main business processes. However, due to the limited space in this research paper, the following table details only the identified result indicators (RI) of the selected business process, and indicates those that respondents identified as the key result indicators (KRI):

Table 2: Identified results indicators of Storage business process

\begin{tabular}{|c|c|c|c|c|c|}
\hline $\begin{array}{l}\text { A group of } \\
\text { indicators }\end{array}$ & Results indicators (RI) & \begin{tabular}{|c|} 
Key \\
RI
\end{tabular} & $\begin{array}{c}\begin{array}{c}\text { Measurement method } \\
\text { (Formula) }\end{array} \\
\end{array}$ & $\begin{array}{c}\text { Meas. } \\
\text { Unit }\end{array}$ & $\begin{array}{l}\text { Evaluation } \\
\text { frequency }\end{array}$ \\
\hline \multirow{6}{*}{$\begin{array}{l}\text { Quantities } \\
\text { and } \\
\text { capacities }\end{array}$} & $\begin{array}{l}\text { Total quantity of declared } \\
\text { seed in stock }\end{array}$ & & $\begin{array}{l}\text { It is determined by the } \\
\text { inventory of goods at the end of } \\
\text { the control period }\end{array}$ & $\mathrm{Kg}, \mathrm{SJ}$ & Per year \\
\hline & $\begin{array}{l}\text { The total amount of } \\
\text { declared seed in stock } \\
\text { with the partner }\end{array}$ & & $\begin{array}{l}\text { It is determined by the } \\
\text { inventory of goods at the end of } \\
\text { the control period }\end{array}$ & $\mathrm{Kg}, \mathrm{SJ}$ & Per year \\
\hline & $\begin{array}{l}\text { Average quantity of } \\
\text { declared seed in condition } \\
\text { (measured in SJ and } \mathrm{kg} \text { ) }\end{array}$ & & $\begin{array}{l}\text { Total stored quantity / Number } \\
\text { of days in the measurement } \\
\text { period }\end{array}$ & Number & Seasonal \\
\hline & $\begin{array}{l}\text { Average occupancy of } \\
\text { shelving capacity } \\
\text { according to the number } \\
\text { of pallet places }\end{array}$ & & $\begin{array}{l}\text { Average number of occupied } \\
\text { pallet places / Projected } \\
\text { capacities }\end{array}$ & $\%$ & Seasonal \\
\hline & $\begin{array}{l}\text { Average floor storage } \\
\text { occupancy (tons) }\end{array}$ & & $\begin{array}{l}\text { Average quantity of seeds in } \\
\text { stock / Projected storage } \\
\text { capacities }\end{array}$ & $\%$ & Seasonal \\
\hline & $\begin{array}{l}\text { The share of this season's } \\
\text { production in seed stocks } \\
\text { by varieties and hybrids }\end{array}$ & & $\begin{array}{l}\text { Average quantity of goods this } \\
\text { season / Average total quantity } \\
\text { of goods in stock }\end{array}$ & $\%$ & Per year \\
\hline
\end{tabular}




\begin{tabular}{|c|c|c|c|c|}
\hline & Inventory turnover ratio & $\begin{array}{l}\text { Cost of finished products / } \\
\text { average value of stocks }\end{array}$ & Number & Per year \\
\hline & $\begin{array}{l}\text { Average turnover period - } \\
\text { by plant species }\end{array}$ & $\begin{array}{l}365 \text { days / Inventory turnover } \\
\text { ratio }\end{array}$ & $\begin{array}{c}\text { Number } \\
\text { of days }\end{array}$ & Per year \\
\hline \multirow[t]{2}{*}{ Quality } & $\begin{array}{l}\text { Seed quality in stock by } \\
\text { varieties and hybrids } \\
\text { (conditional / } \\
\text { unconditional) }\end{array}$ & \begin{tabular}{l|l} 
- & $\begin{array}{l}\text { Based on laboratory reports, a } \\
\text { cross-section of the current } \\
\text { situation }\end{array}$ \\
\end{tabular} & $\%$ & Per year \\
\hline & Average seed age in stock & - $\quad \begin{array}{l}\text { (Quantity per lot* Batch age + } \\
\mathrm{Q} 2 * \mathrm{Ba} 2 \ldots+\mathrm{Qn} * \text { Ban)/ total } \\
\text { seed quantity) }\end{array}$ & $\begin{array}{l}\text { Number } \\
\text { of years }\end{array}$ & Per year \\
\hline Incomes & $\begin{array}{l}\text { Deviation from the } \\
\text { storage revenue plan }\end{array}$ & $\begin{array}{c}\text { (((Realized storage income - } \\
\text { planned storage income }) / \\
\text { planned storage income })+1) * \\
100\end{array}$ & $\%$ & $\begin{array}{c}\text { Per } \\
\text { month, } \\
\text { Per year }\end{array}$ \\
\hline \multirow[b]{2}{*}{ Costs } & Direct storage costs & $\begin{array}{l}\text { (salaries, fuel, telephone } \\
\text { bills...) }\end{array}$ & RSD & Per year \\
\hline & $\begin{array}{l}\text { Relationship between } \\
\text { storage costs and the } \\
\text { value of goods by } \\
\text { warehouses }\end{array}$ & $\begin{array}{l}\text { Value of stored goods / storage } \\
\text { costs }\end{array}$ & Index & Per year \\
\hline \multirow{5}{*}{$\begin{array}{c}\text { Operational } \\
\text { indicators }\end{array}$} & $\begin{array}{l}\text { Number of total shipped } \\
\text { SJ }\end{array}$ & $\begin{array}{l}\text { Data according to issued } \\
\text { delivery notes }\end{array}$ & SJ & Seasonal \\
\hline & Average realization time & $\begin{array}{l}\text { Average waiting time for } \\
\text { loading / unloading }\end{array}$ & $\begin{array}{c}\text { Number } \\
\text { of } \\
\text { minutes }\end{array}$ & Seasonal \\
\hline & Speed of manipulation & $\begin{array}{l}\text { Average time required for } \\
\text { vehicle loading / unloading } \\
\text { operation }\end{array}$ & $\begin{array}{c}\text { Number } \\
\text { of } \\
\text { minutes }\end{array}$ & Seasonal \\
\hline & $\begin{array}{l}\text { Participation of errors in } \\
\text { the realization of loading / } \\
\text { unloading of vehicles }\end{array}$ & $\begin{array}{l}\text { Number of recorded errors / } \\
\text { total number of executed orders }\end{array}$ & $\%$ & Seasonal \\
\hline & $\begin{array}{l}\text { Level of seed damage in } \\
\text { the warehouse } \\
\text { (manipulation and } \\
\text { infected seeds) }\end{array}$ & $\begin{array}{l}\text { Number of recorded errors / } \\
\text { total number of executed orders }\end{array}$ & $\%$ & Seasonal \\
\hline
\end{tabular}

Source: the author

In their questionnaires, the respondents very often identified the metrics used for the evaluation of the indicators with the indicator itself. For example, they cited Deviations from the Storage Revenue Plan as a performance indicator, although this is actually only a metric (measure) for evaluating performance for the Storage Revenue Performance Indicator. The metrics used for performance evaluation implicitly contain two metrics related to the expected and achieved values for the observed performance indicator. In the context of system implementation in a particular organization, it is important to note that the result indicators shown in the table, as well as those marked as key, are presented as seen by the respondents. An organization that desires to implement its performance 
measurement and evaluation system necessarily needs to make additional effort to identify indicators relevant to its own business.

Organizations that start by implementing business process performance measurement systems mainly initially focus on result indicators (past). Transition from measurement to performance management is characterized by focusing on performance indicators (future), which allows monitoring the level of the provided critical success factors, and taking timely action to provide the desired level of achievement. The literature deals with this type of division into result indicators and performance indicators in detail, but the author believes that this type of classification is not so important in practice, especially not at the beginning. What is more important is an understanding of this issue and invested efforts to introduce a systemic approach to performance management which would lead to better performance of both the teams and processes, and the organization as a whole.

\section{Conclusion}

The research revealed that the average respondent did not recognize the terminological determinants common in technical literature on business process management and performance measurement. After clarification of the terms, a large number of respondents stated that they used some performance measurement, but those were mostly not structured or coordinated activities. Instead of adopting a systemic approach, individual and localized solutions were applied, focusing on monitoring the yield or quality/performance of plant species. Respondents' responses indicate that more work and education is needed to understand the difference between measurement and process management.

In accordance with the above, the conclusion imposes the need for a generic model as a guide for building a business performance management system in the seed industry. Such a generic model would represent an integrated view that would support the management in understanding, analyzing, and (re)designing business logic. From the holistic aspect, it should provide systematic performance management both at the corporate level and in all defined processes of the organization, i.e. offer a unique integrated system for measurement and evaluation of the business process performance. Holistic view is necessary because it establishes the connection between the whole and the parts (Balaban \& Ristić, 2013).

Although the paper lists only a small part of the research needed to build such a model, it can certainly serve as a guide for researchers and practitioners and assist in building their own systems for managing processes and their performance.

\section{References}

Balaban, N., \& Ristić, Ž. (2013). Upravljanje performansom. M\&I SYSTEMS. Co.

Balaban, N., Šereš, L., Belić, K. (2010). Performance management support system in the context of strategic management. Strategic Management, 15(4), 25-35. 
Basu, R., (2008). Implementing Six Sigma and Lean: A practical guide to tools and techniques. Butterworth-Heinemann.

Bititci, U., Carrie, A. \& McDevitt, L. (1997). Integrated performance measurement systems: an audit and development guide. The TQM Magazine, 9(1), 46-53.

Burlton, R., 2001. Business Process Management: Profiting from Process. Indianapolis, IN.: Sams.

Čerović, S. (2013). Upravljanje ljudskim resursima u hotelijerstvu (Treće izdanje). Beograd: Univerzitet Singidunum.

Davenport, T. (1993). Process Innovation: Reengineering Work through Information Technology. Boston, MA: Harvard Business School Press.

Goldratt, E., \& Cox, J. (1986). The goal: a process of ongoing improvement. s.1.:North River Press.

Gubrium, J. F., \& Holstein, J. A. (2001). Handbook of Interview Research: Context and Method. SAGE Publications, Inc.

Hammer, M. (1990). Reengineering work: don't automate, obliterate. Harward Business Review, Issue July-Avgust.

Hammer, M., \& Champy, J. (1993). Reengineering the Corporation: A Manifesto for Business Evolution. New York: Harper Business.

Harmon, P. (2003). Business process Change, A Manager's Guide to Improving, Redesigning, and Automating Processes. San Francisco: Morgan Kaufman Publishers.

Kaplan, R., \& Norton, D. (1993). Putting the balanced scorecard to work. Harvard Business Review, 9/10,134-47.

Komljenović, I. (2003). Ratarsko povrtarski priručnik (Opšte ratarstvo). Laktaši: Grafomarsk.

Joglekar, A. (2003). Statistical methods for Six Sigma: In $R \& D$ and Manufacturing. New Jersey: John Wiley \& Sons.

Maskell, B. H. (1992). Performance measurement for world class manufacturing. Corporate Controller (COP), Tom January/February, 44-8.

McCormack, K., \& Johnson, W. (2001). Business Process Orientation-Gaining the EBusiness Competitive Advantage. s.1.:St. Lucie Press, FL.

Neely, A. (2002). Business Performance Measurement: Theory and Practice. Cambridge: Cambridge University Press.

Oppenheim, A. (1992). Questionnaire Design, Interviewing and Attitude Measurement. London: Continuum.

Parmenter, D. (2007). Key Performance Indicators - Developing, Implementing, and Using Winning KPIs. Hoboken, New Jersey: John Wiley \& Sons, Inc. 
Rb1. (2006). Pravilnik o kontroli proizvodnje semena, sadržini i načinu vođenja evidencije o proizvodnji rasada poljoprivrednog bilja i obrascu izveštaja o proizvodnji micelija jestivih i lekovitih gljiva. "Službeni glasnik RS", Tom 60/2006.

Rb2. (2010). Pravilnik o priznavanju sorti poljoprivrednog bilja. "Službeni glasnik RS", Tom 30/2010.

Rummler, G., \& Brache, A. (1995). Improving Performance: How to Manage the White Space on the Organizational Chart. San Francisco, CA.: Jossey-Bass.

Salah, S., Carretero, J., \& Rahim, A. (2009). Six Sigma and Total Quality Management (TQM): similarities, differences and relationship. International Journal of Six Sigma and Competitive Advantage, 5(3).

Sandeep, V., \& Harpreet, B. (2016). Are subjective business performance measures justified? International Journal of Productivity and Performance Management, 65, 603621.

Turajlić, N., Nešković, S., \& Vučković, M., (2009). Mesto mera performansi u modelima poslovnih procesa. INFOTEH-JAHORINA, 8(E-III-18), 598-602.

Watts, T., \& McNair-Connolly, C. (2012). New performance measurement and managementcontrol systems, s.1.: University of Wollongong.

ZoS. (2005). Zakon o semenu poljoprivrednog bilja. Službeni glasnik RS , 45/2005. 